\title{
Review \\ The Prospect of Repurposing Immunomodulatory Drugs for Adjunctive Chemotherapy against Tuberculosis: A Critical Review
}

\author{
Chiyun Lee ${ }^{1,2}$ and Sanjib Bhakta ${ }^{2, *(1)}$ \\ 1 Department of Biochemistry, University of Cambridge, Hopkins Building, Tennis Court Road, \\ Cambridge CB2 1QW, UK; cl724@cam.ac.uk \\ 2 Mycobacteria Research Laboratory, Department of Biological Sciences, The Institute of Structural and \\ Molecular Biology, Birkbeck, University of London, Malet Street, London WC1E 7HX, UK \\ * Correspondence: s.bhakta@bbk.ac.uk or sanjib.bhakta@ucl.ac.uk
}

check for

updates

Citation: Lee, C.; Bhakta, S. The Prospect of Repurposing Immunomodulatory Drugs for Adjunctive Chemotherapy against Tuberculosis: A Critical Review. Antibiotics 2021, 10, 91. https:// doi.org/10.3390/antibiotics10010091

Received: 18 December 2020

Accepted: 16 January 2021

Published: 19 January 2021

Publisher's Note: MDPI stays neutral with regard to jurisdictional claims in published maps and institutional affiliations.

Copyright: (c) 2021 by the authors. Licensee MDPI, Basel, Switzerland. This article is an open access article distributed under the terms and conditions of the Creative Commons Attribution (CC BY) license (https:// creativecommons.org/licenses/by/ $4.0 /)$.

\begin{abstract}
Tuberculosis (TB) remains a global health emergency, with an estimated 2 billion people infected across the world, and 1.4 million people dying to this disease every year. Many aspects of the causative agent, Mycobacterium tuberculosis, make this disease difficult for healthcare and laboratory researchers to fight against, such as unique pathophysiology, latent infection and long and complex treatment regimens, thus causing patient non-compliance with the treatment. Development of new drugs is critical for tackling these problems. Repurposing drugs is a promising strategy for generating an effective drug treatment whilst circumventing many of the challenges of conventional drug development. In this regard, the incorporation of immunomodulatory drugs into the standard regimen to potentiate frontline drugs is found to be highly appealing. Drugs of diverse chemical classes and drug categories are increasingly being evidenced to possess antitubercular activity, both in vitro and in vivo. This article explores and discusses the molecular entities that have shown promise in being repurposed for use in anti-TB adjunctive therapy and aims to provide the most up-to-date picture of their progress.
\end{abstract}

Keywords: tuberculosis; drug resistance; repurposing; immunomodulatory drugs; NSAIDs; adjunctive therapy; potentiator

\section{Tuberculosis: The Disease, the Immunobiology and the Available Treatment}

Despite the recent resurgence in political will to fight tuberculosis (TB), the disease remains as a leading cause of death from a single infectious agent around the world [1]. Every year, an estimated 1.2 million deaths are caused by TB in the HIV-negative population with a further 208,000 deaths from those who are HIV-positive. Roughly a quarter of the world is infected-around 2 billion-and 10 million new cases are said to develop every year, making TB still an extremely prevalent disease. Moreover, the disease has a distinct geographical distribution, with the most heavily burdened countries often being of lower income, strongly coinciding with where HIV infection rates are rampant too. The milestones and targets set by The End TB Strategy push public healthcare and interdisciplinary science capabilities to the limit.

The causative agent of TB is Mycobacterium tuberculosis, a slow-growing acid-fast bacillus manifesting itself primarily as a respiratory pathogen causing pulmonary disease. It can also cause extra-pulmonary TB via systemic infection, and its pathogens are capable of crossing the blood-brain barrier. This dangerous pathogen is required to be handled in a Biosafety Level 3 environment, and in conjunction with its slow-growing nature, makes for an especially difficult bacterium to study. Adding to its unique physiology are its cell wall [2], biofilms [3] and notorious drug efflux pumps [4], which work together to efficiently ruin many of our attempts to develop drugs against it. 
Granulomas are the iconic immunological host response to TB infection [5]. The structurally organised cluster of macrophages and lymphocytes is the immune system's most fundamental strategy for containing the spread of infection and eliminating the entrapped bacilli [6]. Although granulomas are capable of sterilising infection foci, M. tuberculosis can enter a state of dormancy in response to stresses making it remarkably more tolerant to immune responses as well as antibiotic chemotherapy [6]. The majority of the infected population is described to be in this state of latent TB infection (LTBI), showing no overt symptoms.

Reawakening from this persistence state is a slow, stochastic and poorly understood process. TNF- $\alpha$ is a linchpin of the anti-TB response as it recruits immune cells and drives the formation and maintenance of granulomas. Transient immunosuppression, for example in anti-TNF therapy, provides stimulus for bacilli to reawaken and cause active disease [7,8]. Immunosuppressive diseases, such as diabetes mellitus and HIV, are linked with higher susceptibility to active TB. As much as $10 \%$ of the TB-infected population in HIV endemic regions are estimated to have active disease as a result of co-infection [1].

The nature of TB enhances the development of resistance to antibiotics. Bacilli emerging from persistence generate a constant influx of cells of varying levels of physiological resistance, facilitating the selection of genetic resistance. Granulomas also diminish the penetration of antibiotics, exposing the bacilli to a decreased concentration of the drugs too [9]. Finally, it is no surprise that the current gruelling 6-month regimen of rifampicin, isoniazid, ethambutol and pyrazinamide sees suboptimal compliance, further promoting resistance.

The prospect of vaccines eradicating TB seems far into the future as the latest M72/ AS01E vaccine only provides protection in half of those administered after three years [10], and efficacy of the BCG vaccine against adult pulmonary disease is highly disputed [11]. Moreover, it took an astonishing 40 years, after the golden era of antibiotic discovery, for an anti-TB drug with a completely unique mechanism of action to be developed and then become approved by the FDA $[12,13]$. It is evident that the low-hanging fruit for novel antimicrobials has been long picked.

\section{The Prospect of Repurposing}

In the midst of all these interconnected factors that hinder TB eradication, drug repurposing is a prospective strategy. Drugs that are repurposed for TB can fast-track initial stages of drug development as safety trials, and pharmacokinetic/pharmacodynamic (PK/PD) testing has been performed during testing for other disease conditions. The potential reduced financial investments and faster rollouts of novel treatment strategies make repurposing highly desirable in the light of the new drug development pipeline drying up. There are numerous leaps forward of repurposing in other fields, as well as many prospective leads in the repurposing of anti-infectives for TB, such as anti-helminthic drug pyrvinium pamoate, which protects against extensively drug-resistant TB (XDR-TB) in murine models [14], and various antibiotic classes, including fluoroquinolones, nitroimidazoles, $\beta$-lactam / $\beta$-lactamase inhibitor combinations and oxazolidinones. Moxifloxacin has been successfully repurposed as second-line treatment for TB [15], and several other fluoroquinolones are in clinical trials to shorten TB treatment or are in pre-clinical development [16], whilst novel derivatives from nitroimidazole, pretomanid and delamanid have been approved for use in TB patients and have numerous late clinical trials aiming to incorporate them into combination therapies [17]. There has also been a resurgence of interest in $\beta$-lactams owing to the discovery of $\beta$-lactamase inhibitors, clavulanate and avibactam, and they are featured in several clinical trials [18-21]. Although originally for Gram-positive bacteria, oxazolidinones-linezolid and its derivatives-are in many clinical trials, with linezolid already approved for use in TB [22]. In addition, the antiparasitic artemisinin is currently receiving a lot of attention from the research community for its ability to disrupt signalling that regulates persistence in $M$. tuberculosis [23-26].

In a disease with such a heavy involvement of immunology as TB infection, the potential for host-directed therapies (HDTs) is overwhelming $[27,28]$. The power to reduce 
excessive lung damage and enhance bactericidal capacity of the immune system is immense, all the while avoiding the risk of resistance seen in antimicrobials. A controlled dampening of the immune system to stimulate reawakening of the bacteria may be exploited to predispose the awakening bacteria to elimination by first-line drugs and shorten treatment due to elimination of the dormant reservoir [29].

Whether repurposing immunomodulatory drugs is a selective leg-up or a silver bullet will require further investigation and close analysis of our first steps in this approach.

\section{Repurposing Immunomodulatory Compounds}

There are numerous aspects of inflammation that differentially determine the outcome of immunity against TB. Excessive inflammation and necrosis can overwhelm the lung's ability to repair itself and even spread the infection, whilst too weak of an immune response will disrupt granuloma integrity and release the bacilli [30]. Little has been elucidated about what predisposes an infected individual to either extreme of the inflammatory response, but in the meantime, there have been countless attempts to pharmacologically modulate and correct the immune response in adjunct therapy alongside the standard anti-TB drug regimen (see Table 1 for a general overview).

One of the most investigated out of these is vitamin D due to the link between vitamin D deficiency and TB susceptibility and its potential to stimulate autophagy and the production of antimicrobial peptides [31]. Another welcome observation of vitamin D is its direct growth inhibition of mycobacteria in vitro [32]. Being essential for our natural consumption, vitamins are particularly easy to investigate in clinical trials as they come with few safety concerns, attributed to the numerous studies on vitamins in host-directed therapy and countless retrospective studies on vitamin D supplementation [33]. However, studies show conflicting results on the efficacy of vitamin $\mathrm{D}$ in adjunct therapy, with some showing accelerated sputum culture conversion only in multi-drug-resistant TB (MDR-TB) patients but not overall in the study [34], whilst others detect no effect whatsoever [35]. Many studies do highlight an improved quality of life for a specific subset of patients, which perhaps points to us requiring more investigation on patient markers for effective vitamin D adjunctive therapy, the sensitivity for which retrospective studies are likely to lack. Despite so much investigation in this area, the future of vitamins in TB is still unclear. Regardless, it is tempting to make vitamin supplementation a standard procedure for TB-infected individuals in regions of the world where malnutrition and natural vitamin deficiencies suppresses the immune system.

Corticosteroids are a clinically important drug class used in modulating the immune system in other illnesses and have also attracted a lot of attention for potential host-directed therapy. The more pronounced differential organ-specific effects of corticosteroids may make it hard to repurpose them for use in a general immunomodulatory adjunct therapy, however [36]. This leaves corticosteroids to be primarily used for reducing excessive inflammation in the severest cases of meningitis TB for now, as a study of prednisolone in HIV-associated pulmonary TB showed no survival benefit but showed a reduction in clinical complications [36,37]. Their ability to influence anti-TB drug accumulation in different compartments of the body can perhaps be exploited in a customised organ-specific therapy for various extrapulmonary foci of TB infection.

\subsection{Immunomodulation Is Diverse}

Immunomodulatory properties are not exclusive to drugs classically considered as general-purpose anti-inflammatory drugs. The histone deacetylase inhibitor, phenylbutyrate, used originally for urea cycle disorders, has seen several successful clinical trials that indicate a diverse array of immunomodulatory functions in TB infection [38-40]. Furthermore, the notorious thalidomide, used originally for morning sickness, has been frequently investigated for its use in meningitis TB therapy due to its antagonistic effect on TNF- $\alpha$ for its potential to limit excessive inflammation [41,42]. Though alleviating symptoms, the 
counter-productive T cell co-stimulatory properties of thalidomide and, most importantly, its teratogenicity restrict its translation of immunomodulatory properties in the clinic [43].

The chemical diversity of molecular entities possessing immunomodulatory potential repeatedly exceeds expectation. Auranofin is a peculiar molecule consisting of a gold atom conjugated to a saccharide, used in the treatment of rheumatoid arthritis, which can make $M$. tuberculosis prone to reactive oxygen species (ROS) and reactive nitrogen intermediates (RNI) attack, currently investigated in a phase II trial (NCT02968927). The concept of repurposing drugs opens our eyes to the opportunity to make better use of our entire arsenal of therapeutic molecules. Our conventional expectation for what confers therapeutic efficacy may be limiting our potential to treat disease.

A wilder example is seen in doxycycline. Although originally developed for its effect on bacteria and not the host, doxycycline in fact exerts a direct effect on human matrix metalloproteinases. M. tuberculosis infection reprograms the host tissue environment and causes destruction to lung tissue, making the potential of doxycycline to counteract these phenomena highly attractive [44]. A mouse model of TB infection demonstrates the potency of doxycycline in stabilising lung tissue integrity and increasing the concentration of firstline anti-TB drugs in the lung tissue [45]. A clinical trial investigating its efficacy in humans has been completed, and its results are awaited (NCT02774993).

A similar effect of optimising drug distribution is seen in drugs used for cardiovascular disorders. Verapamil, a drug used for treating high blood pressure, potentiates standard TB therapy in mice, additionally exerting a direct inhibitory effect on $M$. tuberculosis $[46,47]$. Its ability to reduce the MIC of bedaquiline in vitro and increase the bioavailability of bedaquiline in mouse models makes it a very promising drug to follow in the future [48].

The cholesterol-lowering statins show a variety of properties which give them good potential for repurposing in adjunctive TB therapy. The effect of pravastatin on macrophages phenocopies that of classically activated macrophages, whilst all members of the drug class exert an inhibitory effect on TB-infected macrophage ex vivo models [49]. Some statins also show synergy with first-line drugs in vitro and in vivo, highlighting their multi-pronged effect in inhibiting TB growth. A retrospective analysis reveals protection from LTBI in statin users [50], and one phase II trial investigating rosuvastatin in adjunctive therapy is underway (NCT04504851). However, concerns about the detrimental effects on host immunity arise from cases of rapid progression of bladder cancer upon statin use [51], as well as the drug interaction with the anti-TB drug rifampicin [44], warranting further investigation before repurposing is possible [52].

The same study by Magee, M.J. et al. [50] revealed metformin use to also protect against LTBI, once again highlighting the well-established link between diabetes mellitus and TB susceptibility [53]. Following from these disease associations, the evidence supporting metformin use as an adjunctive drug is building in both mouse models [54] and in the clinic $[55,56]$.

Another large class of drugs being investigated for anti-TB adjunct therapy is the phosphodiesterase inhibitors (PDE-I). Unlike non-steroidal anti-inflammatory drugs (NSAIDs), phosphodiesterase inhibitors target a family of host enzymes that are divergent in function. Although PDE-I all block the degradation of second messenger intracellular cyclic nucleotides to modulate intracellular signalling, the distributions of the different phosphodiesterases is tissue-specific, and thus inhibitors of different isoforms of phosphodiesterase produce a unique profile of effect. In one experimental model the PDE-5 inhibitor sildenafil is observed to prolong death in mice without decreasing bacterial burden, whilst PDE-3 inhibitor cilostazol does in fact reduce bacterial load in lungs [57]. This can be somewhat explained by how PDE-5 is found predominantly in lung tissue and PDE-3 in macrophages and platelets [58]. In drugs with such varied modulatory effects on intracellular signalling, it would be important to commence animal model studies promptly to evaluate the net effect of all the individual effects on different tissues. Overall, various inhibitors of PDE-3, -4 and -5 have demonstrated excellent anti-TB activity and synergy with frontline drugs in mouse and rabbit models and are soon to enter clinical trials as adjunct therapy [59-61]. 


\subsection{Anti-Cancer Drugs}

Repurposing for TB therapeutics is recently taking inspiration from cancer therapeutics, which perhaps is no surprise due to the role of immunomodulation at the microenvironment level in both diseases. Imatinib targets host tyrosine kinases and was originally designed for Abl kinase-driven cancers, though mouse model experiments of imatinib against TB show that its immunomodulatory effects are translatable [62]. Indeed, a recent case was of a chronic myeloid leukaemia patient undergoing imatinib therapy whose latent TB had reawakened [63]. A phase II trial is scheduled to commence shortly to investigate this (NCT03891901). TNF- $\alpha$ inhibitors and LT- $\alpha$ inhibitors, highly successful in cancer treatment, also show potential for repurposing, as an in vitro granuloma model reveals their ability to resuscitate dormant TB via controlled immunosuppression [64]. There is a recent burst of exploration into similar molecules, such as nilotinib, gefitinib and fostamatinib, each showing varied mechanisms of action, for example, enhancing autophagy [65-67].

Cancer research also arguably boasts the most innovative strategies in therapeutics. Biologics contrast the small molecule drugs discussed thus far but have demonstrated many successes in cancer. Denileukin diftitox, used against $\mathrm{T}$ cell lymphomas, is a fusion protein of diphtheria toxin and human CD25 receptor, targeting regulatory $\mathrm{T}$ cells for killing by the toxin component to revert immunosuppressive microenvironments in a mouse model [68]. Research here is still in its early stages, and it has been proposed that these biologics may in fact be detrimental in TB infection [69]. The work needed for successful repurposing is immense, but these early findings on the potential of biologics in anti-TB therapeutics may breathe new life into how we approach developing new therapies against the disease. Chimeric antigen receptor (CAR)-T cell therapy describes the ex vivo gene editing of antigen receptors of patient $\mathrm{T}$ cells before re-introduction into patients for enhanced immunity in cancers [70]. Perhaps CAR-T cell therapy can be adopted for use in the treatment of TB.

There remain many drugs of diverse purpose that are investigated for their repurposing value in isolated pockets of research. Diosmin, used normally for haemorrhoids, was discovered in silico as a repurposable drug and demonstrates protection in a Drosophila TB model, also highlighting the potential of in silico methods to find new leads [71]. Lipoxygenase inhibitors were proposed as immunomodulators after inhibition of host lipoxygenase improved survival in a mouse model [33,72]. Antiviral isoprinosine resuscitates the immune system dampened by viruses during infection and can potentially be repurposed for use against TB [73]. In addition to phenylbutyrate, histone acetylase inhibitors valproic acid and vorinostat, originally developed for neurological disorders and cancers, respectively, show synergy with frontline drugs in a macrophage model [39]. Phenothiazines have been deemed too toxic in several clinical trials [74,75], whereas the MIC of the thiocarbamate, disulfuram, was found to be too high. Disulfuram has recently been further repurposed to act as a copper ion chelator to deliver bactericidal activity in vitro [76].

\subsection{Non-Steroidal Anti-Inflammatory Drugs}

Non-steroidal anti-inflammatory drugs (NSAIDs) are a large and diverse class of drugs that inhibit cyclooxygenase (COX) to reduce prostaglandin production, thereby alleviating inflammation, fever and pain [77]. Although the WHO recommends administering NSAIDs for TB patients, they are aimed at relieving the joint pain caused by anti-TB drugs and directly helping with the infection itself. In recent years, there has been a growing body of science to support the use of NSAIDs in adjunctive therapy, especially as some members of the NSAIDs chemical class are available as over-the-counter medication, making them easier to repurpose.

The most studied NSAID currently in TB research is ibuprofen. This common drug found in most households has been found to demonstrate a direct inhibitory effect in wholecell screening assays [78] and most importantly provide protection against TB in mouse animal models $[79,80]$. A newer paper calls into question the validity of the disease model in the latter papers, however, criticising the use of intravenous (IV) infection as opposed 
to a more representative respiratory infection route used in their paper, demonstrating that ibuprofen and celecoxib are in fact detrimental for immunity against TB [81]. The author reasoned that an IV infection using an unphysiological thousand-fold higher dose of $M$. tuberculosis would trigger massive inflammation which an anti-inflammatory drug would, of course, alleviate. The importance of the quality of disease models is acutely emphasised in a complex disease like TB. Nevertheless, we await the results for a phase II clinical trial investigating the use of ibuprofen as adjunctive therapy in extensively drugresistant TB (NCT02781909). The results from this study will be valuable in discerning the significance of the many conflicting findings of the pre-clinical research.

Aspirin is another common household NSAID which received attention in the TB research community. Although initially shown to potentiate the first-line drug, pyrazinamide, in a murine model [82], its undesirable drug interactions with isoniazid [83] and lack of significant effect observed in the more powerful rabbit TB model shows little promise for aspirin as an immune-modulatory adjunctive drug [43]. Instead, aspirin holds greater potential for use as a general anti-inflammatory drug for a disease driven by excessive inflammation, such as meningitis $\mathrm{TB}$, as opposed to one which demands a finer balance of the different arms of immunity as in pulmonary TB. One clinical study showed aspirin in combination with corticosteroids reduces strokes and mortality in tuberculous meningitis [84], and we will see the results of a similar ongoing study soon (NCT02237365).

Etoricoxib, meloxicam and celecoxib form the remaining NSAIDs which have been studied in clinical trials. The results from a recent study attempting to determine the safety of etoricoxib as an adjunct for the novel H56:IC31 vaccine are eagerly being awaited as we see the first steps of a vaccine that targets reinfection and relapsing TB infection, as well as a NSAID used as an immunostimulant for vaccine response (NCT02503839). The results from the long-completed phase III clinical study on meloxicam in preventing TB-immune reconstituted inflammatory syndrome (TB-IRIS) have yet to be published (NCT02060006). Finally, celecoxib was investigated in a phase I ex vivo trial for adjunctive therapy which showed no effect, though the significance of an ex vivo model is unknown (NCT02602509).

Some NSAIDs which have fallen away from the spotlight are oxyphenbutazone, diflunisal and bromfenac [85]. Their progression beyond their in vitro inhibitory potential is thwarted perhaps by concerns about toxicity [86]. The toxicity profile of diclofenac appears to be deemed too dangerous for its observed synergy in a murine model with former first-line antibiotic, streptomycin, to warrant further investigation [87].

The host-directed therapeutic effects of NSAIDs vary predominantly via their different pharmacokinetic properties, as opposed to varying via alternative mechanisms, exerting differential effects based on tissue location and cell type. Carprofen is an NSAID recently found to lean strongly towards direct antitubercular-specific mechanisms of action, in contrast to the majority of NSAIDs, boasting a minimum inhibitory concentration (MIC) of $40 \mu \mathrm{g} / \mathrm{mL}$, well within the MIC range of most antibiotics [78]. Traditionally, a drug with a pathogen-directed activity would bring up concerns about the development of resistance. However, carprofen demonstrates a pleiotropic mechanism of action, disrupting efflux pumps, biofilms and membrane potentials, which lessens the risk and effect of resistance mutations [88]. In conjunction with its classical NSAID effects, carprofen proves to be a promising candidate for further testing in animal models for its potential to simultaneously revert tolerance to first-line TB drugs through inhibition of efflux pumps, directly inhibit growth and exert a host-directed immunomodulatory effect. Having been used in human medicine for over 10 years but later repositioned for veterinary use for commercial reasons, carprofen should face greater ease in repurposing as an anti-TB adjunct drug [89].

The discovery of more anti-tuberculosis adjunctive drugs and potentiator molecules may be facilitated by following strategies used in the development of an effective combination therapy against TB. Hypomorphs describe $M$. tuberculosis strains engineered to have reduced expression of a gene that is essential for function. Screening a library of repurposable compounds against various hypomorph strains allows for greater sensitivity in detecting compounds with inhibitory effects on particular pathways [90]. This may be 
especially important in targeting pathways that are more difficult to observe as having relevance during initial in vitro whole-cell screens but are critical in vivo, such as mycobacterial HsaD. The $h s a D$ (Rv3569c) gene is found to be essential for mycobacterial cholesterol metabolism within macrophages, and its hypomorphs have been used to identify and develop novel chemical leads in antibiotic discovery [91], highlighting the potential for a similar approach to be used to identify candidate repurposed drugs.

As for the more classical NSAIDs, given the role of prostaglandins in antagonising TNF- $\alpha$, IL-1 $\beta$, ROS and RNI, there is obvious potential for NSAIDs enhancing killing of M. tuberculosis through inhibition of COX [77]. However, the whole picture seems far more complex as prostaglandins are also essential for reducing early mitochondrial damage and bias macrophages towards apoptosis instead of necrosis [92]. As apoptosis drives both innate and adaptive immune defence mechanisms, prostaglandins have effects on both arms of immunity. Furthermore, some virulent strains of TB can be seen to inhibit COX-2 production themselves [77]. In the study of such multi-functional drugs against such a multi-faceted disease, it is critical to use animal models that more closely mimic the intricacies of human pulmonary TB like cavitating lung granulomas, which the rabbit or $\mathrm{C} 3 \mathrm{HeB} / \mathrm{FeJ}$ mouse models achieve, as this would allow the potential of NSAIDs to be assessed with greater accuracy. Additionally, while NSAIDs have a justified role due to their antimicrobial mechanisms of action in the proposed adjunctive therapy, the timing of administration and route of drug delivery would be critical in modulating the immune response appropriately. Such resource-intensive testing for whether individual TB patients are appropriate for administration strays far from a simple and standardised drug regimen for reducing the prevalence of such a widespread disease. Only further research and clinical testing can help us answer these questions. 
Table 1. Summary table of the most promising immunomodulatory drugs discussed in this literature review currently under investigation for their potential to be repurposed as an adjunct drug for the standard anti-TB drug regimen.

\begin{tabular}{|c|c|c|c|c|c|c|c|}
\hline Drug Class & Name & Original Indication & Delivery Route & FDA Approval & Clinical Trial Progression & Availability & Key References \\
\hline Biologic & Denileukin diftitox & $\begin{array}{c}\text { Cutaneous T cell } \\
\text { lymphoma }\end{array}$ & IV & 1999 & - & $\mathrm{PO}$ & [68] \\
\hline ССВ & Verapamil & Angina & Oral & 1981 & - & $\mathrm{PO}$ & {$[46,47]$} \\
\hline HDACi & Phenylbutyrate & Urea cycle disorders & Oral & 1996 & $\begin{array}{l}\text { NCT01580007 Phase II } \\
\text { trial completed } 2018\end{array}$ & $\mathrm{PO}$ & [38-40] \\
\hline HDACi & Valproic acid & Epilepsy & Oral & 1978 & - & $\mathrm{PO}$ & [39] \\
\hline HDACi & Vorinostat & $\begin{array}{l}\text { Cutaneous T cell } \\
\text { lymphoma }\end{array}$ & Oral & 2006 & - & $\mathrm{PO}$ & {$[39]$} \\
\hline LOi & - & $\begin{array}{c}\text { Asthma, neoplasms, } \\
\text { arthritis }\end{array}$ & - & - & - & - & {$[33,72]$} \\
\hline NSAID & Aspirin & Arthritis, analgesic & Oral & 1950 & $\begin{array}{l}\text { NCT02237365 Phase II } \\
\text { trial awaiting results }\end{array}$ & OTC & {$[43,82-84]$} \\
\hline NSAID & Carprofen & Analgesic & Oral & 1987 & - & VUO & {$[78,88]$} \\
\hline NSAID & Celecoxib & Arthritis & Oral & 1998 & $\begin{array}{l}\text { NCT02602509 Phase I } \\
\text { trial completed }\end{array}$ & $\mathrm{PO}$ & {$[33,81]$} \\
\hline NSAID & Etoricoxib & $\begin{array}{l}\text { Inflammatory } \\
\text { disorders }\end{array}$ & Oral & - & $\begin{array}{l}\text { NCT02503839 Phase I } \\
\text { trial underway }\end{array}$ & $\mathrm{PO}$ & {$[29,33]$} \\
\hline NSAID & Ibuprofen & Arthritis, analgesic & Oral & 1974 & $\begin{array}{l}\text { NCT02781909 Phase II } \\
\text { trial underway }\end{array}$ & OTC & [79-82] \\
\hline NSAID & Meloxicam & Arthritis & Oral & 2000 & $\begin{array}{l}\text { NCT02060006 Phase III } \\
\text { trial awaiting results }\end{array}$ & $\mathrm{PO}$ & [33] \\
\hline PDEi & Cilostazol & $\begin{array}{l}\text { Cardiovascular } \\
\text { disorders }\end{array}$ & Oral & 1999 & - & $\mathrm{PO}$ & {$[57-61]$} \\
\hline PDEi & Sildenafil & Erectile dysfunction & Oral & 1998 & - & $\mathrm{PO}$ & {$[57-61]$} \\
\hline Statins & Pravastatin & $\begin{array}{l}\text { Cardiovascular } \\
\text { disorders }\end{array}$ & Oral & 1991 & $\begin{array}{l}\text { NCT04504851 Phase II } \\
\text { trial underway }\end{array}$ & $\mathrm{PO}$ & [49] \\
\hline Statins & Rosuvastatin & $\begin{array}{l}\text { Cardiovascular } \\
\text { disorders }\end{array}$ & Oral & 2003 & $\begin{array}{l}\text { NCT04504851 Phase II } \\
\text { trial in planning }\end{array}$ & $\mathrm{PO}$ & {$[50]$} \\
\hline TC & Doxycycline & Bacterial infections & Oral & 1967 & $\begin{array}{l}\text { NCT02774993 Phase II } \\
\text { trial awaiting results }\end{array}$ & $\mathrm{PO}$ & {$[44,45]$} \\
\hline TNFi & - & $\begin{array}{l}\text { Autoimmune } \\
\text { disorders }\end{array}$ & - & - & - & - & [8] \\
\hline TKI & Fostamatinib & $\begin{array}{l}\text { Chronic immune } \\
\text { thrombocytopenia }\end{array}$ & Oral & 2018 & - & $\mathrm{PO}$ & {$[65-67]$} \\
\hline TKI & Gefitinib & $\begin{array}{l}\text { Metastatic non-small } \\
\text { cell lung cancer }\end{array}$ & Oral & 2003 & - & $\mathrm{PO}$ & {$[65-67]$} \\
\hline TKI & Imatinib & $\begin{array}{l}\text { Chronic myeloid } \\
\text { leukaemia }\end{array}$ & Oral & 2001 & $\begin{array}{l}\text { NCT03891901 Phase II } \\
\text { trial in planning }\end{array}$ & $\mathrm{PO}$ & {$[62,63]$} \\
\hline TKI & Nilotinib & $\begin{array}{c}\text { Chronic myeloid } \\
\text { leukaemia }\end{array}$ & Oral & 2007 & - & $\mathrm{PO}$ & [65-67] \\
\hline Vitamin & Vitamin D & Vitamin & Oral & - & $\begin{array}{l}\text { Several clinical } \\
\text { trials completed }\end{array}$ & OTC & {$[31-35]$} \\
\hline - & Auranofin & Rheumatoid arthritis & Oral & 1985 & $\begin{array}{l}\text { NCT02968927 Phase II } \\
\text { trial awaiting results }\end{array}$ & $\mathrm{PO}$ & [93] \\
\hline - & $\begin{array}{l}\text { Diosmin } \\
\text { Isoprinosine }\end{array}$ & $\begin{array}{l}\text { Haemorrhoids } \\
\text { Viral infections }\end{array}$ & $\begin{array}{c}\text { Oral }^{1} \\
\text { Oral }\end{array}$ & - & $\begin{array}{l}- \\
-\end{array}$ & - & $\begin{array}{l}{[71]} \\
{[73]}\end{array}$ \\
\hline- & Thalidomide & Leprosy & Oral & 1998 & $\begin{array}{l}\text { Several clinical } \\
\text { trials completed }\end{array}$ & $\mathrm{PO}$ & {$[38-40]$} \\
\hline
\end{tabular}

Abbreviations: CCB, calcium channel blocker; HDACi, histone deacetylase inhibitor; IV, intravenous; LOi, lipoxygenase inhibitor; NSAID, non-steroidal anti-inflammatory drug; OTC, over the counter; PDEi, phosphodiesterase inhibitor; PO, prescription-only; TC, tetracycline; TKI, tyrosine kinase inhibitor; TNFi, tumour necrosis factor inhibitor; VUO, veterinary use only. ${ }^{1}$ Also available as topical medication.

\section{Conclusions}

In the midst of rising antibiotic resistance and the uncertain future for conventional new drug design, repurposing immunomodulatory drugs has potential to hold tremendous value for TB research. Despite promising clinical trials in this area, the many conflicting pieces of evidence leave some key questions unanswered (Figure 1). Are the effects of immunomodulatory drugs suitable for incorporation into a standardised anti-TB treatment or should they be reserved for patient-tailored treatment? Can drugs be directly repurposed against TB or will drugs have to undergo further chemical modification, thereby reducing/increasing further challenges? How much of the effect of these repurposed drugs is host-directed and how much is pathogen-directed? Following this, what are the long-term off-target/adverse effects on the host and how great is the risk of development of resistance? Many inquiries remain before repurposed immunomodulatory drugs can become a standard anti-TB chemotherapy. To tackle the questions that hinder us from achieving this goal, multi-disciplinary research must be conducted at a greater pace and scale, and yet still with caution, given the significant potential of immunomodulation to also cause complexity in TB pathophysiology. 


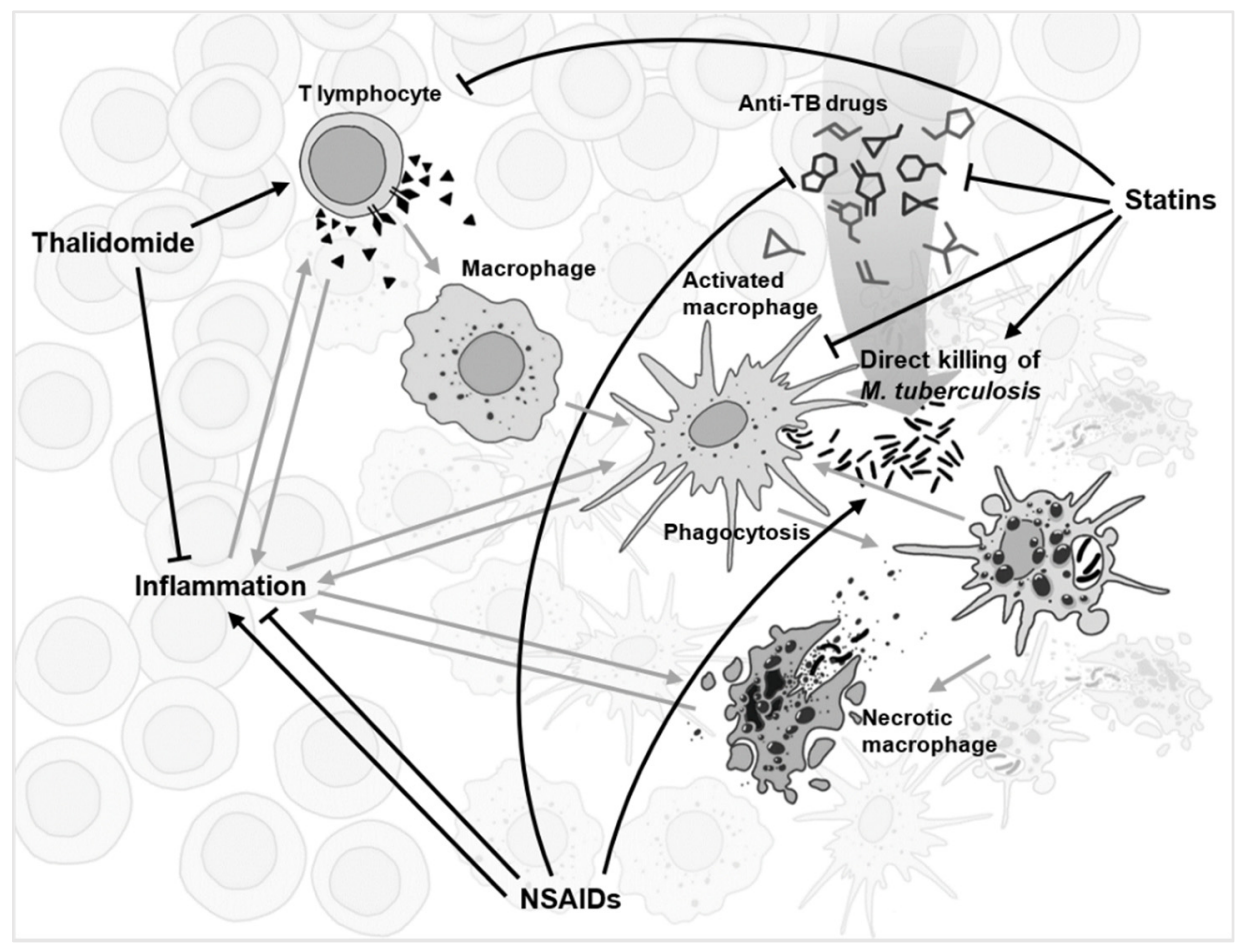

Figure 1. A simplified schematic of the complex network of interactions (grey) during tuberculosis infection within a granuloma. Several drugs with the most conflicting experimental evidence, and yet with repurposing potential for anti-TB adjunct therapy, are displayed with their suggested network of interactions shown (black).

Author Contributions: S.B. conceived the project, C.L. designed and wrote the first draft of the manuscript and created the illustration, all under supervision of S.B. The manuscript was edited and revised by C.L. and S.B. All authors have read and agreed to the published version of the manuscript.

Funding: This research received no external funding.

Acknowledgments: We would like to thank the Institute of Structural and Molecular Biology (http:/ / www.ismb.lon.ac.uk/) for supporting C.L.'s summer internship.

Conflicts of Interest: The authors declare no conflict of interest.

\section{References}

1. World Health Organization. Global Tuberculosis Report. 2020. Available online: https://www.who.int/tb/publications/global_ report/en/ (accessed on 9 December 2020).

2. Maitra, A.; Munshi, T.; Healy, J.; Martin, L.T.; Vollmer, W.; Keep, N.H.; Bhakta, S. Cell wall peptidoglycan in Mycobacterium tuberculosis: An Achilles' heel for the TB-causing pathogen. FEMS Microbiol. Rev. 2019, 43, 548-575. [CrossRef]

3. Sambandan, D.; Dao, D.N.; Weinrick, B.C.; Vilchèze, C.; Gurcha, S.S.; Ojha, A.; Kremer, L.; Besra, G.S.; Hatfull, G.F.; Jacobs, W.R. Keto-Mycolic acid-dependent pellicle formation confers tolerance to drug-sensitive Mycobacterium tuberculosis. MBio 2013, 4, 1-10. [CrossRef]

4. Machado, D.; Coelho, T.S.; Perdigão, J.; Pereira, C.; Couto, I.; Portugal, I.; Maschmann, R.D.A.; Ramos, D.F.; von Groll, A.; Rossetti, M.L.R.; et al. Interplay between mutations and efflux in drug resistant clinical isolates of Mycobacterium tuberculosis. Front. Microbiol. 2017, 8, 711. [CrossRef]

5. Ferluga, J.; Yasmin, H.; Al-Ahdal, M.N.; Bhakta, S.; Kishore, U. Natural and trained innate immunity against Mycobacterium tuberculosis. Immunobiology 2020, 225, 151951. [CrossRef]

6. Gupta, A.; Kaul, A.; Tsolaki, A.G.; Kishore, U.; Bhakta, S. Mycobacterium tuberculosis: Immune evasion, latency and reactivation. Immunobiology 2012, 217, 363-374. [CrossRef]

7. Gengenbacher, M.; Kaufmann, S.H.E. Mycobacterium tuberculosis: Success through dormancy. FEMS Microbiol. Rev. 2012, 36, 514-532. [CrossRef]

8. Zhang, Z.; Fan, W.; Yang, G.; Xu, Z.; Wang, J.; Cheng, Q.; Yu, M. Risk of tuberculosis in patients treated with TNF- $\alpha$ antagonists: A systematic review and meta-analysis of randomised controlled trials. BMJ Open 2017, 7, e012567. [CrossRef] 
9. Cicchese, J.M.; Dartois, V.; Kirschner, D.E.; Linderman, J.J. Both Pharmacokinetic Variability and Granuloma Heterogeneity Impact the Ability of the First-Line Antibiotics to Sterilize Tuberculosis Granulomas. Front. Pharmacol. 2020, 11, 333. [CrossRef]

10. Tait, D.R.; Hatherill, M.; Der Meeren, O.; Van Ginsberg, A.M.; Van Brakel, E.; Salaun, B.; Scriba, T.J.; Akite, E.J.; Ayles, H.M.; Bollaerts, A.; et al. Final analysis of a trial of M72/AS01E vaccine to prevent tuberculosis. N. Engl. J. Med. 2019, 381, $2429-2439$. [CrossRef]

11. de Gijsel, D.; von Reyn, C.F. A Breath of Fresh Air: BCG Prevents Adult Pulmonary Tuberculosis. Int. J. Infect. Dis. 2019, 80, S6-S8. [CrossRef]

12. Mahajan, R. Bedaquiline: First FDA-approved tuberculosis drug in 40 years. Int. J. Appl. Basic Med. Res. 2013, 3, 1-2. [CrossRef]

13. da Cunha, B.R.; Fonseca, L.P.; Calado, C.R.C. Antibiotic discovery: Where have we come from, where do we go? Antibiotics 2019, 8, 45. [CrossRef]

14. Guan, Q.; Zhan, L.; Liu, Z.H.; Pan, Q.; Chen, X.L.; Xiao, Z.; Qin, C.; Zhang, X.L. Identification of pyrvinium pamoate as an anti-tuberculosis agent in vitro and in vivo by SOSA approach amongst known drugs. Emerg. Microbes Infect. 2020, 9, 302-312. [CrossRef]

15. Gillespie, S.H. The role of moxifloxacin in tuberculosis therapy. Eur. Respir. Rev. 2016, 25, 19-28. [CrossRef]

16. Pranger, A.D.; van der Werf, T.S.; Kosterink, J.G.W.; Alffenaar, J.W.C. The Role of Fluoroquinolones in the Treatment of Tuberculosis in 2019. Drugs 2019, 79, 161-171. [CrossRef]

17. Lewis, J.M.; Sloan, D.J. The role of delamanid in the treatment of drug-resistant tuberculosis. Ther. Clin. Risk Manag. 2015, 11, 779-791.

18. Xiao, S.; Guo, H.; Weiner, W.S.; Maddox, C.; Mao, C.; Gunosewoyo, H.; Pelly, S.; White, L.E.; Rasmussen, L.; Schoenen, F.J.; et al. Revisiting the $\beta$-Lactams for Tuberculosis Therapy with a Compound-Compound Synthetic Lethality Approach. Antimicrob. Agents Chemother. 2019, 63, e01319-19. [CrossRef]

19. Deshpande, D.; Srivastava, S.; Chapagain, M.; Magombedze, G.; Martin, K.R.; Cirrincione, K.N.; Lee, P.S.; Koeuth, T.; Dheda, K.; Gumbo, T. Ceftazidime-avibactam has potent sterilizing activity against highly drug-resistant tuberculosis. Sci. Adv. 2017, 3, e1701102. [CrossRef]

20. Deshpande, D.; Srivastava, S.; Bendet, P.; Martin, K.R.; Cirrincione, K.N.; Lee, P.S.; Pasipanodya, J.G.; Dheda, K.; Gumbo, T. Antibacterial and sterilizing effect of benzylpenicillin in tuberculosis. Antimicrob. Agents Chemother. 2018, 62, e02232-17. [CrossRef]

21. Levine, S.R.; Beatty, K.E. Investigating $\beta$-lactam drug targets in. bioRxiv 2019, 1-16. [CrossRef]

22. Huynh, J.; Marais, B.J. Multidrug-resistant tuberculosis infection and disease in children: A review of new and repurposed drugs. Ther. Adv. Infect. Dis. 2019, 6, 1-16. [CrossRef]

23. Kalani, K.; Chaturvedi, V.; Trivedi, P.; Tondon, S.; Srivastava, S.K. Dihydroartemisinin and its Analogs: A New Class of Antitubercular Agents. Curr. Top. Med. Chem. 2019, 19, 594-599. [CrossRef]

24. Patel, Y.S.; Mistry, N.; Mehra, S. Repurposing artemisinin as an anti-mycobacterial agent in synergy with rifampicin. Tuberculosis 2019, 115, 146-153. [CrossRef]

25. Zheng, H.; Williams, J.T.; Aleiwi, B.; Ellsworth, E.; Abramovitch, R.B. Inhibiting Mycobacterium tuberculosis DosRST Signaling by Targeting Response Regulator DNA Binding and Sensor Kinase Heme. ACS Chem. Biol. 2020, 15, 52-62. [CrossRef]

26. Martini, M.C.; Zhang, T.; Williams, J.T.; Abramovitch, R.B.; Weathers, P.J.; Shell, S.S. Artemisia annua and Artemisia afra extracts exhibit strong bactericidal activity against Mycobacterium tuberculosis. J. Ethnopharmacol. 2020, 262, 113191. [CrossRef]

27. Kaufmann, S.H.E.; Dorhoi, A.; Hotchkiss, R.S.; Bartenschlager, R. Host-directed therapies for bacterial and viral infections. Nat. Rev. Drug Discov. 2017, 17, 35-56. [CrossRef]

28. Arranz-Trullén, J.; Lu, L.; Pulido, D.; Bhakta, S.; Boix, E. Host antimicrobial peptides: The promise of new treatment strategies against tuberculosis. Front. Immunol. 2017, 8, 1499. [CrossRef]

29. Anastasopoulou, A.; Ziogas, D.C.; Samarkos, M.; Kirkwood, J.M.; Gogas, H. Reactivation of tuberculosis in cancer patients following administration of immune checkpoint inhibitors: Current evidence and clinical practice recommendations. J. Immunother. Cancer 2019, 7, 239. [CrossRef]

30. Ndlovu, H.; Marakalala, M.J. Granulomas and inflammation: Host-directed therapies for tuberculosis. Front. Immunol. 2016, 7, 434. [CrossRef]

31. Campbell, G.R.; Spector, S.A. Autophagy induction by vitamin D inhibits both Mycobacterium tuberculosis and human immunodeficiency virus type 1. Autophagy 2012, 8, 1523-1525. [CrossRef]

32. Greenstein, R.J.; Su, L.; Brown, S.T. Vitamins A \& D Inhibit the Growth of Mycobacteria in Radiometric Culture. PLoS ONE 2012, 7, e29631.

33. Young, C.; Walzl, G.; Du Plessis, N. Therapeutic host-directed strategies to improve outcome in tuberculosis. Mucosal Immunol. 2020, 13, 190-204. [CrossRef]

34. Jolliffe, D.A.; Ganmaa, D.; Wejse, C.; Raqib, R.; Haq, M.A.; Salahuddin, N.; Daley, P.K.; Ralph, A.P.; Ziegler, T.R.; Martineau, A.R. Adjunctive vitamin D in tuberculosis treatment: Meta-analysis of individual participant data. Eur. Respir. J. 2019, 53, 1802003. [CrossRef] [PubMed]

35. Soeharto, D.A.; Rifai, D.A.; Marsudidjadja, S.; Roekman, A.E.; Assegaf, C.K.; Louisa, M. Vitamin D as an Adjunctive Treatment to Standard Drugs in Pulmonary Tuberculosis Patients: An Evidence-Based Case Report. Adv. Prev. Med. 2019, $2019,5181847$. [CrossRef] [PubMed] 
36. Schutz, C.; Davis, A.G.; Sossen, B.; Lai, R.P.J.; Ntsekhe, M.; Harley, Y.X.R.; Wilkinson, R.J. Corticosteroids as an adjunct to tuberculosis therapy. Expert Rev. Respir. Med. 2018, 12, 881-891. [CrossRef] [PubMed]

37. Kumarvelu, S.; Prasad, K.; Khosla, A.; Behari, M.; Ahuja, G.K. Randomized controlled trial of dexamethasone in tuberculous meningitis. Tuber. Lung Dis. 1994, 75, 203-207. [CrossRef]

38. Bekele, A.; Gebreselassie, N.; Ashenafi, S.; Kassa, E.; Amogne, W.; Tefera, M.; Aseffa, A.; Worku, A.; Raqib, R.; Agerberth, B.; et al. Daily adjunctive therapy with vitamin D3 and phenylbutyrate supports clinical recovery from pulmonary tuberculosis: A randomized controlled trial in Ethiopia. J. Intern Med. 2019, 284, 292-306. [CrossRef]

39. Rao, M.; Valentini, D.; Zumla, A.; Maeurer, M. Evaluation of the efficacy of valproic acid and suberoylanilide hydroxamic acid (vorinostat) in enhancing the effects of first-line tuberculosis drugs against intracellular Mycobacterium tuberculosis. Int. J. Infect. Dis. 2018, 69, 78-84. [CrossRef]

40. Mily, A.; Rekha, R.S.; Kamal, S.M.M.; Arifuzzaman, A.S.M.; Rahim, Z.; Khan, L.; Haq, M.A.; Zaman, K.; Bergman, P.; Brighenti, S.; et al. Significant effects of oral phenylbutyrate and Vitamin D3 adjunctive therapy in pulmonary tuberculosis: A randomized controlled trial. PLoS ONE 2015, 10, e0138340. [CrossRef]

41. Congreve, M.; Chessari, G.; Tisi, D.; Woodhead, A.J. Recent Developments in Fragment-Based Drug Discovery. J. Med. Chem. 2008, 51, 3661-3680. [CrossRef]

42. Schoeman, J.F.; Springer, P.; van Rensburg, A.J.; Swanevelder, S.; Hanekom, W.A.; Haslett, P.A.J.; Kaplan, G. Adjunctive thalidomide therapy for childhood tuberculous meningitis: Results of a randomized study. J. Child Neurol. 2004, 19, 250-257. [CrossRef] [PubMed]

43. Kumar, R.; Kolloli, A.; Singh, P.; Vinnard, C.; Kaplan, G.; Subbian, S. Thalidomide and Phosphodiesterase 4 Inhibitors as Host Directed Therapeutics for Tuberculous Meningitis: Insights From the Rabbit Model. Front. Cell. Infect. Microbiol. 2020,9 , 450. [CrossRef] [PubMed]

44. Sabir, N.; Hussain, T.; Mangi, M.H.; Zhao, D.; Zhou, X. Matrix metalloproteinases: Expression, regulation and role in the immunopathology of tuberculosis. Cell Prolif. 2019, 52, e12649. [CrossRef]

45. Xu, Y.; Wang, L.; Zimmerman, M.D.; Chen, K.-Y.; Huang, L.; Fu, D.-J.; Kaya, F.; Rakhilin, N.; Nazarova, E.V.; Bu, P.; et al. Matrix metalloproteinase inhibitors enhance the efficacy of frontline drugs against Mycobacterium tuberculosis. PLoS Pathog. 2018, 14, e1006974. [CrossRef]

46. Huang, J.; Brumell, J.H. Bacteria-autophagy interplay: A battle for survival. Nat. Rev. Microbiol. 2014, 12, 101-114. [CrossRef]

47. Chen, C.; Gardete, S.; Jansen, R.S.; Shetty, A.; Dick, T.; Rhee, K.Y.; Dartoisa, V. Verapamil targets membrane energetics in Mycobacterium tuberculosis. Antimicrob. Agents Chemother. 2018, 62, e02107-17. [CrossRef]

48. Xu, J.; Tasneen, R.; Peloquin, C.A.; Almeida, D.V.; Li, S.Y.; Barnes-Boyle, K.; Lu, Y.; Nuermberger, E. Verapamil increases the bioavailability and efficacy of bedaquiline but not clofazimine in a murine model of tuberculosis. Antimicrob. Agents Chemother. 2018, 62, 1-8. [CrossRef]

49. Dutta, N.K.; Bruiners, N.; Zimmerman, M.D.; Tan, S.; Dartois, V.; Gennaro, M.L.; Karakousis, P.C. Adjunctive host-directed therapy with statins improves tuberculosis-related outcomes in mice. J. Infect. Dis. 2020, 221, 1079-1087. [CrossRef]

50. Magee, M.J.; Salindri, A.D.; Kornfeld, H.; Singhal, A. Reduced prevalence of latent tuberculosis infection in diabetes patients using metformin and statins. Eur. Respir. J. 2019, 53, 1-4. [CrossRef]

51. Hoffmann, P.; Roumeguère, T.; Schulman, C.; Van Velthoven, R. Use of statins and outcome of BCG treatment for bladder cancer. N. Engl. J. Med. 2006, 355, 2705-2707. [CrossRef]

52. Cilloniz, C.; Torres, A. Statins as Adjunctive Therapy Against Tuberculosis (TB): The Balance Between Statin-Induced Anti-TB Effect and Trained Immunity Suppression To. J. Infect. Dis. 2020, 222, 334-335. [CrossRef]

53. Naicker, N.; Sigal, A.; Naidoo, K. Metformin as Host-Directed Therapy for TB Treatment: Scoping Review. Front. Microbiol. 2020, 11, 435. [CrossRef]

54. Singhal, A.; Jie, L.; Kumar, P.; Hong, G.S.; Leow, M.K.S.; Paleja, B.; Tsenova, L.; Kurepina, N.; Chen, J.; Zolezzi, F.; et al. Metformin as adjunct antituberculosis therapy. Sci. Transl. Med. 2014, 6, 263ra159. [CrossRef]

55. Lee, Y.J.; Han, S.K.; Park, J.H.; Lee, J.K.; Kim, D.K.; Chung, H.S.; Heo, E.Y. The effect of metformin on culture conversion in tuberculosis patients with diabetes mellitus. Korean J. Intern. Med. 2018, 33, 933-940. [CrossRef]

56. Degner, N.R.; Wang, J.Y.; Golub, J.E.; Karakousis, P.C. Metformin Use Reverses the Increased Mortality Associated with Diabetes Mellitus during Tuberculosis Treatment. Clin. Infect. Dis. 2018, 66, 198-205. [CrossRef]

57. Maiga, M.C.; Ahidjo, B.A.; Maiga, M.; Bishai, W.R. Roflumilast, a Type 4 phosphodiesterase inhibitor, shows promising adjunctive, host-directed therapeutic activity in a mouse model of tuberculosis. Antimicrob. Agents Chemother. 2015, 59, 7888-7890. [CrossRef]

58. Maiga, M.; Agarwal, N.; Ammerman, N.C.; Gupta, R.; Guo, H.; Maiga, M.C.; Lun, S.; Bishai, W.R. Successful shortening of tuberculosis treatment using adjuvant host-directed therapy with FDA-approved phosphodiesterase inhibitors in the mouse model. PLoS ONE 2012, 7, e30749. [CrossRef]

59. Leukes, V.; Walzl, G.; du Plessis, N. Myeloid-Derived Suppressor Cells as Target of Phosphodiesterase-5 Inhibitors in HostDirected Therapeutics for Tuberculosis. Front. Immunol. 2020, 11, 1-7. [CrossRef]

60. Subbian, S.; Tsenova, L.; Holloway, J.; Peixoto, B.; O’Brien, P.; Dartois, V.; Khetani, V.; Zeldis, J.B.; Kaplan, G. Adjunctive Phosphodiesterase-4 Inhibitor Therapy Improves Antibiotic Response to Pulmonary Tuberculosis in a Rabbit Model. EBioMedicine 2016, 4, 104-114. [CrossRef] 
61. Subbian, S.; Tsenova, L.; O’Brien, P.; Yang, G.; Koo, M.S.; Peixoto, B.; Fallows, D.; Zeldis, J.B.; Muller, G.; Kaplan, G. Phosphodiesterase-4 inhibition combined with isoniazid treatment of rabbits with pulmonary tuberculosis reduces macrophage activation and lung pathology. Am. J. Pathol. 2011, 179, 289-301. [CrossRef]

62. Napier, R.J.; Rafi, W.; Cheruvu, M.; Powell, K.R.; Zaunbrecher, M.A.; Bornmann, W.; Salgame, P.; Shinnick, T.M.; Kalman, D. Imatinib-Sensitive tyrosine kinases regulate mycobacterial pathogenesis and represent therapeutic targets against tuberculosis. Cell Host Microbe 2011, 10, 475-485. [CrossRef]

63. Chandra, A.; Rao, N.; Malhotra, K.P. Renal tuberculosis in an imatinib-treated chronic myeloid leukemia. Braz. J. Nephrol. 2020, 42, 366-369. [CrossRef]

64. Arbués, A.; Brees, D.; Chibout, S.D.; Fox, T.; Kammüller, M.; Portevin, D. TNF- $\alpha$ antagonists differentially induce TGF $\beta 1-$ dependent resuscitation of dormant-like Mycobacterium tuberculosis. PLoS Pathog. 2020, 16, e1008312. [CrossRef]

65. Hussain, T.; Zhao, D.; Shah, S.Z.A.; Sabir, N.; Wang, J.; Liao, Y.; Song, Y.; Dong, H.; Hussain Mangi, M.; Ni, J.; et al. Nilotinib: A Tyrosine Kinase Inhibitor Mediates Resistance to Intracellular Mycobacterium Via Regulating Autophagy. Cells $2019,8,506$. [CrossRef]

66. Sogi, K.M.; Lien, K.A.; Johnson, J.R.; Krogan, N.J.; Stanley, S.A. The Tyrosine Kinase Inhibitor Gefitinib Restricts Mycobacterium tuberculosis Growth through Increased Lysosomal Biogenesis and Modulation of Cytokine Signaling. ACS Infect. Dis. 2017, 3, 564-574. [CrossRef]

67. Mourenza, Á.; Gil, J.A.; Mateos, L.M.; Letek, M. Novel Treatments against Mycobacterium tuberculosis Based on Drug Repurposing. Antibiotics 2020, 9, 550. [CrossRef]

68. Gupta, S.; Cheung, L.; Pokkali, S.; Winglee, K.; Guo, H.; Murphy, J.R.; Bishai, W.R. Suppressor Cell-Depleting Immunotherapy with Denileukin Diftitox is an Effective Host-Directed Therapy for Tuberculosis. J. Infect. Dis. 2017, 215, 1883-1887. [CrossRef]

69. Dobler, C.C. Biologic Agents and Tuberculosis. Microbiol. Spectr. 2016, 4, 1-12. [CrossRef]

70. Parida, S.K.; Poiret, T.; Zhenjiang, L.; Meng, Q.; Heyckendorf, J.; Lange, C.; Ambati, A.S.; Rao, M.V.; Valentini, D.; Ferrara, G.; et al T-Cell Therapy: Options for Infectious Diseases. Clin. Infect. Dis. 2015, 61, S217-S224. [CrossRef]

71. Pushkaran, A.C.; Vinod, V.; Vanuopadath, M.; Nair, S.S.; Nair, S.V.; Vasudevan, A.K.; Biswas, R.; Mohan, C.G. Combination of Repurposed Drug Diosmin with Amoxicillin-Clavulanic acid Causes Synergistic Inhibition of Mycobacterial Growth. Sci. Rep. 2019, 9, 1-14. [CrossRef]

72. Mayer-Barber, K.D.; Andrade, B.B.; Oland, S.D.; Amaral, E.P.; Barber, D.L.; Gonzales, J.; Derrick, S.C.; Shi, R.; Pavan, N. Hostdirected therapy of tuberculosis based on interleukin-1 and type I interferon crosstalk. Nature 2016, 511, 99-103. [CrossRef] [PubMed]

73. Mishra, A.K.; Yabaji, S.M.; Dubey, R.K. Evaluation of isoprinosine to be repurposed as an adjunct anti-tuberculosis chemotherapy. Med. Hypotheses 2018, 115, 77-80. [CrossRef] [PubMed]

74. Purhonen, M.; Koponen, H.; Tiihonen, J.; Tanskanen, A. Determinants of cholesterol and triglycerides recording in patients treated with lipid lowering therapy in UK primary care. Pharmacoepidemiol. Drug Saf. 2007, 16, 228.

75. Amaral, L.; Viveiros, M. Why thioridazine in combination with antibiotics cures extensively drug-resistant Mycobacterium tuberculosis infections. Int. J. Antimicrob. Agents 2012, 39, 376-380. [CrossRef]

76. Dalecki, A.G.; Haeili, M.; Shah, S.; Speer, A.; Niederweis, M.; Kutsch, O.; Wolschendorf, F. Disulfiram and copper ions kill Mycobacterium tuberculosis in a synergistic manner. Antimicrob. Agents Chemother. 2015, 59, 4835-4844. [CrossRef]

77. Ivanyi, J.; Zumla, A. Nonsteroidal antiinflammatory drugs for adjunctive tuberculosis treatment. J. Infect. Dis. 2013, 208, 185-188. [CrossRef]

78. Guzman, J.D.; Evangelopoulos, D.; Gupta, A.; Birchall, K.; Mwaigwisya, S.; Saxty, B.; McHugh, T.D.; Gibbons, S.; Malkinson, J.; Bhakta, S. Antitubercular specific activity of ibuprofen and the other 2-arylpropanoic acids using the HT-SPOTi whole-cell phenotypic assay. BMJ Open 2013, 3, e002672. [CrossRef]

79. Kroesen, V.M.; Rodríguez-Martínez, P.; García, E.; Rosales, Y.; Díaz, J.; Martín-Céspedes, M.; Tapia, G.; Sarrias, M.R.; Cardona, P.J.; Vilaplana, C. A beneficial effect of low-dose aspirin in a murine model of active tuberculosis. Front. Immunol. $2018,9,798$. [CrossRef]

80. Vilaplana, C.; Marzo, E.; Tapia, G.; Diaz, J.; Garcia, V.; Cardona, P.J. Ibuprofen therapy resulted in significantly decreased tissue bacillary loads and increased survival in a new murine experimental model of active tuberculosis. J. Infect. Dis. 2013, 208, 199-202. [CrossRef]

81. Mortensen, R.; Clemmensen, H.S.; Woodworth, J.S.; Therkelsen, M.L.; Mustafa, T.; Tonby, K.; Jenum, S.; Agger, E.M.; Dyrhol-Riise, A.M.; Andersen, P. Cyclooxygenase inhibitors impair CD4 T cell immunity and exacerbate Mycobacterium tuberculosis infection in aerosol-challenged mice. Commun. Biol. 2019, 2, 1-10. [CrossRef]

82. Byrne, S.T.; Denkin, S.M.; Zhang, Y. Aspirin and ibuprofen enhance pyrazinamide treatment of murine tuberculosis. J. Antimicrob. Chemother. 2007, 59, 313-316. [CrossRef] [PubMed]

83. Byrne, S.T.; Denkin, S.M.; Zhang, Y. Aspirin antagonism in isoniazid treatment of tuberculosis in mice. Antimicrob. Agents Chemother. 2007, 51, 794-795. [CrossRef] [PubMed]

84. Misra, U.; Kalita, J.; Sagar, B.; Bhoi, S. Does adjunctive corticosteroid and aspirin therapy improve the outcome of tuberculous meningitis? Neurol. India 2018, 66, 1672-1677. [PubMed] 
85. Gold, B.; Pingle, M.; Brickner, S.J.; Shah, N.; Roberts, J.; Rundell, M.; Bracken, W.C.; Warrier, T.; Somersan, S.; Venugopal, A.; et al. Nonsteroidal anti-inflammatory drug sensitizes Mycobacterium tuberculosis to endogenous and exogenous antimicrobials. Proc. Natl. Acad. Sci. USA 2012, 109, 16004-16011. [CrossRef] [PubMed]

86. Goldkind, L.; Laine, L. A systematic review of NSAIDs withdrawn from the market due to hepatotoxicity: Lessons learned from the bromfenac experience. Pharmacoepidemiol. Drug Saf. 2006, 15, 213-220. [CrossRef]

87. Dutta, N.K.; Mazumdar, K.; Dastidar, S.G.; Park, J.H. Activity of diclofenac used alone and in combination with streptomycin against Mycobacterium tuberculosis in mice. Int. J. Antimicrob. Agents 2007, 30, 336-340. [CrossRef]

88. Maitra, A.; Evangelopoulos, D.; Chrzastek, A.; Martin, L.T.; Hanrath, A.; Chapman, E.; Hailes, H.C.; Lipman, M.; McHugh, T.D.; Waddell, S.J.; et al. Carprofen elicits pleiotropic mechanisms of bactericidal action with the potential to reverse antimicrobial drug resistance in tuberculosis. J. Antimicrob. Chemother. 2020, 75, 3194-3201. [CrossRef]

89. The European Agency for the Evaluation of Medicinal Products: Carprofen Summary Report. Available online: https://www. ema.europa.eu/en/documents/mrl-report/carprofen-summary-report-1-committee-veterinary-medicinal-products_en.pdf (accessed on 16 December 2020).

90. Kana, B.D.; Karakousis, P.C.; Parish, T.; Dick, T. Future target-based drug discovery for tuberculosis? Tuberculosis 2014, 94, 551-556. [CrossRef]

91. Ryan, A.; Polycarpou, E.; Lack, N.A.; Evangelopoulos, D.; Sieg, C.; Halman, A.; Bhakta, S.; Eleftheriadou, O.; McHugh, T.D.; Keany, S.; et al. Investigation of the mycobacterial enzyme $\mathrm{HsaD}$ as a potential novel target for anti-tubercular agents using a fragment-based drug design approach. Br. J. Pharmacol. 2017, 174, 2209-2224. [CrossRef]

92. Kumar, S.; Bansal, K.; Holla, S.; Verma-Kumar, S.; Sharma, P.; Balaji, K.N. ESAT-6 induced COX-2 expression involves coordinated interplay between PI3K and MAPK signaling. Mol. Immunol. 2012, 49, 655-663.

93. Harbut, M.B.; Vilchèze, C.; Luo, X.; Hensler, M.E.; Guo, H.; Yang, B.; Chatterjee, A.K.; Nizet, V.; Jacobs, W.R.; Schultz, P.G.; et al. Auranofin exerts broad-spectrum bactericidal activities by targeting thiol-redox homeostasis. Proc. Natl. Acad. Sci. USA 2015, 112, 4453-4458. [CrossRef] [PubMed] 